\title{
Response of Medium and Long Duration Boro Rice Variety (Oryza sativa L.) to Nitrogen Fertilizer
}

\author{
Amina Khatun $^{1}$, M. K. Quais ${ }^{1}$, A. A. Begum ${ }^{2}$, M. A. Saleque ${ }^{3}$ and M. S. U. Bhuiya ${ }^{4}$ \\ ${ }^{1}$ Rice Farming Systems Division, ${ }^{2}$ Agronomy Division \& ${ }^{3}$ Soil Science Division, Bangladesh Rice \\ Research Institute, Gazipur 1701, Bangladesh; ${ }^{4}$ Department of Agronomy, Bangladesh Agricultural \\ University, Mymensingh 2202, Bangladesh \\ *Corresponding author and Email: aminabrri@gmail.com
}

Received: 20 October 2015

Accepted: 12 December 2016

\begin{abstract}
A field experiment was conducted during November 2009-April 2010 in Bangladesh Rice Research Institute, Bangladesh to examine the response of two rice (Oryza sativa L.) varieties (BRRIdhan28 and BRRI dhan29) to six $\mathrm{N}$ rates of nitrogen fertilizer viz. $0,50,100,150,200$ and $250 \mathrm{~kg} \mathrm{ha}^{-1}$. The experiment was conducted in a RCB design with three replications. Grain yields of both BRRI dhan28 and BRRI dhan 29 increased significantly in a quadratic fashion with $\mathrm{N}$ rates. The highest grain yields were obtained from $150 \mathrm{~kg} \mathrm{~N}^{-1}$ in both the varieties. More than $1 \mathrm{t} \mathrm{ha}^{-1}$ yield was obtained in BRRI dhan29 (6.34 $\left.\mathrm{t} \mathrm{ha}^{-1}\right)$ at the same rate of $\mathrm{N}$ indicated BRRI dhan29 as a nitrogen efficient variety. However, the predicted economic optimum doses of $\mathrm{N}$ appeared to be 156 and $158 \mathrm{~kg} \mathrm{ha}^{-1}$ for BRRI dhan28 and BRRI dhan29, respectively. The grain yield was mainly influenced by the number of panicles per hill, which was found to increase with the increase of $\mathrm{N}$ rates in both the varieties.
\end{abstract}

Keywords: Nitrogen rates, rice, grain yield and yield components, straw yield.

\section{Introduction}

Nitrogen is one of the most yield-limiting nutrients in rice production all over the world (Fageria et al., 2008), especially in tropical Asian soils and it is essential to apply the costly $\mathrm{N}$ fertilizer to get a desirable yield (Khatun et al., 2015a; Saleque et al., 2004). Given the importance of nitrogen fertilization on the yield, it is necessary to know the best dose for the varieties as well as its influence on yield components and other agronomic parameters like plant height and lodging in order to obtain better knowledge of said productive response (Khatun et al., 2015b; Chaturvedi, 2005). However, both excess and insufficient supply of nitrogen is harmful to the rice crop which may decrease grain yield.

Nitrogen is the nutrient normally required in large amounts for lowland rice production (Buresh et al., 1993). Tropical rice-growing soils have a capacity to supply about $40-60 \mathrm{~kg}$ of $\mathrm{N}$ from its inherent reserve of organic matter and from the biological fixation during rice growth, which is sufficient to produce rice yield of 2-3 tha $^{-1}$ (Saleque et al., 2004). Fertilizer N use efficiency of lowland rice is relatively low due to loss of applied $\mathrm{N}$ through leaching, volatilization, surface runoff, and denitrification in the soil-flood water system (Fageria and Baligar, 2001). 
Grain yield in rice is a function of the number of panicles per unit area, number of spikelets per panicle and 1000-grain weight (Fageria et al., 1997). Therefore, it is important to understand the management practices that influence yield components and consequently grain yield. The relationship between rice grain yield and yield components has been studied extensively at the phenotypic level. Number of panicles per plant was the most important component of yield, accounting for $87 \%$ of the variation in yield. Spikelet sterility accounted for $7 \%$ variation in yield, and 1000-grain weight for 3\% variation (Fageria and Baligar, 1999).

A certain part of the applied nitrogen is also immobilized by soil microorganisms and adsorbed on organic matter or soil colloids. The low recovery of nitrogen not only increases cost of crop production but also causes environmental pollution (Fageria et al., 2008). A typical irrigated rice soil in Asia contains about $2800 \mathrm{~kg}$ $\mathrm{N} \mathrm{ha}^{-1}$ in the top $20 \mathrm{~cm}$ of soil where roots derive the majority of crop-N supply. Of this total, the amount of $\mathrm{N}$ derived from indigenous resources during a single cropping cycle typically ranges from $30-100 \mathrm{~kg} \mathrm{~N} \mathrm{ha}^{-1}$, which represents only 1 $4 \%$ of total soil N (Cassman et al., 2002).

The $\mathrm{N}$ fertilization significantly increases grain yield and shoot dry weight. The variation in grain yield with nitrogen fertilization varies from 66 to $93 \%$ depending on genotypes (Khatun et al., 2015a). Similarly, the variation in shoot dry weight with the application of nitrogen fertilizer varied from $58-78 \%$, depending on genotypes. This means $\mathrm{N}$ requirement was higher for grain yield compared to shoot dry matter production (Fageria et al., 2008). Similar results were also reported for lowland rice under Brazilian conditions (Fageria and Baligar, 2005).

Nitrogen is normally a key factor in achieving optimum rice grain yields (Fageria et al., 1997). It is, however, one of the most expensive inputs and if not used properly, can pollute the ground water. Adoption of proper $\mathrm{N}$ management practices such as optimum rate and time of application and use of $\mathrm{N}$ efficient crop genotypes may reduce cost of production and at the same time improve rice yield (Fageria and Filho, 2001).

Development of new technologies and their judicious use are fundamental for achieving potential yield. Making precise $\mathrm{N}$ fertilizer recommendations for higher $\mathrm{N}$-demanding crops like lowland rice is becoming more important as concern grows about the high cost of this input and nitrate pollution of surface and ground waters in agricultural areas (Fageria and Baligar, 1999). Today the environmental as well as financial impact of $\mathrm{N}$ fertilization deserves increased attention. Therefore, the present study was conducted to: i) determine the optimum dose of nitrogen for higher yield, and ii) to see the response of two rice varieties (BRRI dhan28 and BRRI dhan29) to varying levels of $\mathrm{N}$ application.

\section{Materials and Methods}

The field experiment was conducted at Bangladesh Rice Research Institute's experimental farm, Gazipur located at $23^{0} 59^{\prime} \mathrm{N}$ latitude, $90^{\circ} 24^{\prime} \mathrm{E}$ longitude during Boro 2009-10 (November-April) season. The site is about $35 \mathrm{~m}$ above the mean sea level and has a subtropical climate, which is strongly influenced by the southwestern monsoon. It belongs to agroecological zone (AEZ) number 28 known as Madhupur Tract. The average annual rainfall is $2000 \mathrm{~mm}$ with more than $80 \%$ of it occurring from mid-June to the end of September. The mean lowest temperature $\left(15^{\circ} \mathrm{C}\right)$ is observed in January and the highest $\left(30^{\circ} \mathrm{C}\right)$ in May.

The soil of the experimental field is Chhiata clay loam, a member of the fine, hyperthermic Vertic Endoaquept (Saleque et al., 2004). The initial soil chemical properties at $0-15 \mathrm{~cm}$ soil depth were: $\mathrm{pH} 6.1$, organic matter $2.02 \%$, total $\mathrm{N}$ content $0.07 \%$, available phosphorus (P) 10.14 $m g \quad \mathrm{~kg}^{-1} \quad\left(0.5 \quad \mathrm{M} \quad \mathrm{NaHCO}_{3}\right.$ extracted $)$, exchangeable potassium (K) $0.17 \mathrm{c}-\mathrm{mol}(+) / \mathrm{kg}$ soil (Neutral $1.0 \mathrm{~N} \mathrm{NH}_{4} \mathrm{OAc}$ extracted), available sulfur (S) $20 \mathrm{mg} \mathrm{kg}^{-1}\left[\mathrm{Ca}\left(\mathrm{H}_{2} \mathrm{PO}_{4}\right)_{2}\right.$ extracted], 
and available zinc $(\mathrm{Zn}) 2.8 \mathrm{mg} \mathrm{kg}^{-1}(0.01 \mathrm{~N} \mathrm{HCl}$ extracted). The soil of the experimental plot was moderately acidic in nature and poor in fertility status.

Two rice varieties, BRRI dhan 28 and BRRI dhan29 were studied under irrigated conditions during Boro (November-April) season. BRRI dhan28 is a short duration high yielding Boro variety (growth duration 140 days) and BRRI dhan29 is a long duration high yielding Boro variety (growth duration 160 days). The experiment was conducted in a factorial randomized complete block design with three replications. Treatments comprised of two factors viz. two rice varieties and six $\mathrm{N}$ rates. The two rice varieties were BRRI dhan 28 and BRRI dhan 29 and the six $\mathrm{N}$ rates were $0,50,100,150$, 200 and $250 \mathrm{~kg} \mathrm{ha}^{-1}$. Rice seedlings (40-45 days old) were transplanted in the first week of January 2010 and the crop was harvested on 26 April (BRRI dhan28) and 9 May (BRRI dhan29) 2010. Two - three rice seedlings were transplanted at $20 \mathrm{~cm} \times 20 \mathrm{~cm}$ spacing. Unit plot size was $5 \mathrm{~m} \times 4 \mathrm{~m}$. All plots were surrounded by soil levees $30 \mathrm{~cm}$ high to avoid mixing of $\mathrm{N}$ among the plots. After transplanting the seedlings, intercultural operations like weeding, irrigation and pest control operations were done as and when necessary.

Nitrogen was applied as urea in three equal splits at 20,35 and 50 days after transplanting (DAT) for BRRI dhan28 and 20, 35 and 55 DAT for BRRI dhan29. Phosphorus, K, S and Zn were applied as triple super phosphate, muriate of potash, gypsum and zinc sulphate, respectively, during final land preparation as basal dose.

Optimum dose of $\mathrm{N}$ was determined by differentiating the $\mathrm{N}$ response equation (Colwell, 1994). Two equations were compared (i) Quadratic equation and (ii) Square root equation. The form of the quadratic equation is as follows: $\bar{Y}=a+b N+c N^{2}$

Where $\bar{Y}$ was estimated grain yield $\left(\mathrm{kg} \mathrm{ha}^{-1}\right), \mathrm{N}$ was applied nitrogen fertilizer $\left(\mathrm{kg} \mathrm{ha}^{-1}\right), a, b$ and $c$ were regression coefficients.
Differentiating the equation, we got

$\frac{d \bar{Y}}{d N}=b+2 c N$

The optimum dose of $\mathrm{N}$ was at the point where

$\frac{d \bar{Y}}{d N}=0$.

Therefore,

$0=b+2 c N$ or, $N=-\frac{b}{2 c}$

However, the economic optimum dose of $\mathrm{N}$ was

$N=\frac{E_{n}-b}{2 c}$

Where, $E n=\frac{P_{f}}{P_{y}}, P_{\mathrm{f}}$ was price of nutrient $\mathrm{kg}^{-1}$

and $P_{y}$ was price of grains $\mathrm{kg}^{-1}$.

The form of the square-root equation is

$\bar{Y}=a+b N^{0.5}+c N$

The economic optimum dose of $\mathrm{N}$ according to the square-root equation is

$$
N=\left(\frac{0.5 b}{E_{n}-c}\right)^{2}
$$

\section{Estimation of yield and yield components}

At maturity, the crop was harvested manually at ground level. However, 16 hills from each plot were harvested at the ground level for estimating total straw yield. Grain yield was adjusted to $14 \%$ moisture content after sun drying and straw yield was recorded as oven dry basis.

The 16 hills were selected at random from each plot just before harvesting to estimate plant height and tillers numbers. The panicle numbers were determined from 16 hill samples at harvesting. The panicles from the 16 hills were threshed. The grains and sterile spikelets were separated by a seed sorter (Kiya Seisakusho LDT, model 1973, Tokyo, Japan). After separation, the grains and sterile spikelets were counted by an automatic counter (Nagoya, model DC 1-0, Japan). Then the grain numbers per panicle and 1000 grain weight were measured at 
$14 \%$ moisture and sterility (\%) were calculated by following standard procedures as described by (Yoshida et al., 1976). Rice plants from $5 \mathrm{~m}^{2}$ area from the middle of each plot were harvested at the ground level and threshed. The grains were dried in sun, winnowed, weighed and the yield was adjusted to $14 \%$ moisture content and expressed as $\mathrm{t} \mathrm{ha}^{-1}$ using the following formula:

$$
\text { Adjusted weight }=\frac{W \times(100-M 1)}{(100-M 2)} \times 100
$$

Where, $\mathrm{W}$ is the fresh weight of grains and M1 and M2 are the fresh and adjusted moisture percents of grains, respectively.

Sterility was computed by dividing the number of unfilled spikelets by the total number of spikelets (filled grains + unfilled spikelets) and was expressed as percentage as follows:

Sterility $(\%)=\left(\int \frac{\text { Unfilled spikelets }}{\text { Unfilled spikelets }+ \text { filled grains }}\right) \times 100$

Analysis of variance (ANOVA) of the measured parameters was performed and the treatment means were compared using Duncan's multiple range test (DMRT) at the 5\% level of probability (Gomez and Gomez, 1984). The yield and yield components were analyzed by ordinary least squares linear regression as done by Dawe et al. (2000).

\section{Results and Discussion}

\subsection{Plant height}

Nitrogen $(\mathrm{N}) \times$ variety interactions had insignificant effect on plant height. The individual effect of $\mathrm{N}$ and variety on plant height showed significant $(\mathrm{p}<0.01)$ effect (Table 1$)$. The plant height varied from 74 to $94 \mathrm{~cm}$ in BRRI dhan 28 and 73 to $87 \mathrm{~cm}$ in BRRI dhan29. The plant height increased with the increase of $\mathrm{N}$ rates and $250 \mathrm{~kg} \mathrm{~N}^{-1}$ gave the highest plant height and control-N treatment showed the lowest plant height both in BRRI dhan 28 and BRRI dhan29. BRRI dhan28 produced taller plants than BRRI dhan29 irrespective of $\mathrm{N}$ rates. The significant increase in plant height in response to applied $\mathrm{N}$ fertilizers may be attributed to enhanced availability of nitrogen that increased cell division and leaf growth resulting in higher photo assimilates (Chaturvedi, 2005). In T. Aman season, plant height increased with the increasing rates of nitrogen up to $200 \mathrm{~kg}$ $\mathrm{ha}^{-1}$ in BRRI dhan31 and it was found significantly higher from the other levels of nitrogen (Salahuddin et al., 2009). The effects of $\mathrm{N}$ to plant height is easily visible and convinces farmers to apply $\mathrm{N}$ in $\mathrm{N}$ deficient soil. Taller plants resulted from enhanced cell division also has synergies with more tiller production.

\subsection{Tiller and panicle production}

The interaction effects of $\mathrm{N} \times$ variety were insignificant on tiller production (Table 1). The individual effect of $\mathrm{N}$ was significant on tiller production. The tiller number per unit area ranged from 212 to 348 in BRRI dhan 28 and 190 to 359 in BRRI dhan29. In BRRI dhan28, about $64 \%$ of the variations in tillering occurred due to different $\mathrm{N}$ rates and the highest number of tiller was observed in the rate of $250 \mathrm{~kg} \mathrm{~N} \mathrm{ha}^{-1}$. About $89 \%$ of the variations in tiller production occurred due to different $\mathrm{N}$ rates and the highest number of tiller was observed in the rate of 250 $\mathrm{kg} \mathrm{N} \mathrm{ha}{ }^{-1}$ in BRRI dhan29. BRRI dhan29 produced higher number of tillers (295) compared to BRRI dhan28 (270) irrespective of $\mathrm{N}$ rates. But the varietal difference was not significant (Table 1).

The $\mathrm{N}$ and variety interactions showed insignificant $(\mathrm{P}>0.05)$ effect on panicle production (Table 1). The mean effect of variety also demonstrated insignificant effect on panicle $\mathrm{m}^{-2}$. But the mean effect of $\mathrm{N}$ on panicle $\mathrm{m}^{-2}$ was significant. The number of panicles $\mathrm{m}^{-2}$ was increased significantly $(\mathrm{P}<0.01)$ with the application of $\mathrm{N}$ fertilizer both in BRRI dhan28 and BRRI dhan29 rice varieties (Figure 1). A fourth degree polynomial equation explained, almost perfectly, the relationship between $\mathrm{N}$ application and number of panicle per $\mathrm{m}^{2}\left(\mathrm{R}^{2}=\right.$ 1.00) for both BRRI dhan28 and BRRI dhan 29. Number of panicles per unit area is the most important yield contributing trait, which can be manipulated significantly with the $\mathrm{N}$ fertilizer application at an appropriate growth stage. The 
crop cannot utilize nitrogen applied late during the reproductive growth stage in grain yield improvement (Khatun et al., 2015a). Number of effective tillers/hill was significantly influenced by different levels of nitrogen. It was increased with the increasing rates of nitrogen up to $200 \mathrm{~kg}$ $\mathrm{ha}^{-1}$ and found significantly higher from the other levels of nitrogen in BRRI dhan31 (Salahuddin et al., 2009).

\subsection{Number of grains panicle ${ }^{-1}$, sterility and thousand grain weight}

The $\mathrm{N} \times$ variety interactions and the mean effect of $\mathrm{N}$ for grains panicle ${ }^{-1}$ were not significant $(\mathrm{P}>0.05)$ (Table 1). The mean effect of variety for number of grains panicle ${ }^{-1}$ was significant $(\mathrm{P}<0.01)$ (Table 1). BRRI dhan29 produced significantly higher number of grains panicle ${ }^{-1}$ compared to BRRI dhan28. The increase in number of grains per panicle were $31 \%$ in BRRI dhan 28 at $50 \mathrm{~kg} \mathrm{~N} \mathrm{ha}^{-1}$ and $24 \%$ in BRRI dhan29 at $150 \mathrm{~kg} \mathrm{~N}$ ha $^{-1}$ compared to control $\mathrm{N}$ treatment. The highest number of grains panicle ${ }^{-1}$ in BRRI dhan31 was obtained at $150 \mathrm{~kg} \mathrm{ha}^{-1}$, which was significantly different from other $\mathrm{N}$ levels. Nitrogen helped in proper filling of seeds which resulted higher produced plump seeds and thus the number of grains panicle ${ }^{-1}$. The lowest number of grains panicle ${ }^{-1}$ was obtained from 0 $\mathrm{kg} \mathrm{N} \mathrm{ha}^{-1}$ (Salahuddin et al., 2009).

Table 1. Effect of $\mathrm{N}$ application on different yield parameters of BRRI dhan 28 \& BRRI dhan29

\begin{tabular}{|c|c|c|c|c|c|c|}
\hline $\begin{array}{l}\mathrm{N} \text { rate } \\
\left(\mathrm{kg} \mathrm{ha}^{-1}\right)\end{array}$ & $\begin{array}{l}\text { Plant height } \\
(\mathrm{cm})\end{array}$ & $\begin{array}{l}\text { Tiller } \mathrm{m}^{-2} \\
\text { (no.) }\end{array}$ & $\begin{array}{l}\text { Panicle } \\
\mathrm{m}^{-2} \text { (no.) }\end{array}$ & $\begin{array}{c}\text { Grains panicle }^{-} \\
\text {(no.) }\end{array}$ & $\begin{array}{c}1000 \text { grain } \\
\text { wt }(\mathrm{g})\end{array}$ & $\begin{array}{c}\text { Sterility } \\
(\%)\end{array}$ \\
\hline \multicolumn{7}{|c|}{ BRRI dhan28 } \\
\hline 0 & 74 & 212 & 205 & 87 & 20.3 & 30 \\
\hline 50 & 85 & 229 & 219 & 114 & 20.1 & 22 \\
\hline 100 & 90 & 271 & 258 & 100 & 20.1 & 27 \\
\hline 150 & 92 & 303 & 290 & 94 & 20.4 & 23 \\
\hline 200 & 93 & 311 & 292 & 101 & 19.9 & 24 \\
\hline 250 & 94 & 348 & 338 & 99 & 19.4 & 24 \\
\hline Mean & 88 & 270 & 265 & 99 & 20 & 25 \\
\hline \multicolumn{7}{|c|}{ BRRI dhan29 } \\
\hline 0 & 73 & 190 & 167 & 107 & 19.5 & 24 \\
\hline 50 & 78 & 271 & 220 & 119 & 19.4 & 21 \\
\hline 100 & 83 & 282 & 255 & 111 & 19.3 & 22 \\
\hline 150 & 84 & 326 & 268 & 133 & 19.3 & 17 \\
\hline 200 & 84 & 344 & 288 & 118 & 19.2 & 25 \\
\hline 250 & 87 & 359 & 314 & 116 & 18.8 & 24 \\
\hline Mean & 82 & 295 & 252 & 117 & 19 & 22 \\
\hline $\begin{array}{l}\mathrm{LSD}_{0.05} \\
\text { for N }\end{array}$ & 1.05 & 37.72 & 36.01 & 16.41 & 0.44 & 3.59 \\
\hline $\begin{array}{l}\mathrm{LSD}_{0.05} \\
\text { for } \mathrm{V}\end{array}$ & 1.74 & 21.77 & 20.79 & 9.47 & 0.25 & 2.07 \\
\hline $\begin{array}{l}\mathrm{LSD}_{0.05} \\
\text { for } \mathrm{N} \times \mathrm{V}\end{array}$ & 4.27 & 53.34 & 50.93 & 23.21 & 0.62 & 5.07 \\
\hline F-test (N) & $* *$ & $* *$ & $* *$ & NS & $*$ & $* *$ \\
\hline F-test (V) & $* *$ & NS & NS & $* *$ & $* *$ & $* *$ \\
\hline $\begin{array}{l}\text { F-test } \\
(\mathrm{N} \times \mathrm{V})\end{array}$ & NS & NS & NS & NS & NS & NS \\
\hline $\mathrm{CV}(\%)$ & 3.5 & 13 & 13.6 & 14.9 & 2.2 & 14.9 \\
\hline
\end{tabular}

*, **, NS significant at the 0.05 and 0.01 probability levels and non-significant, respectively. 


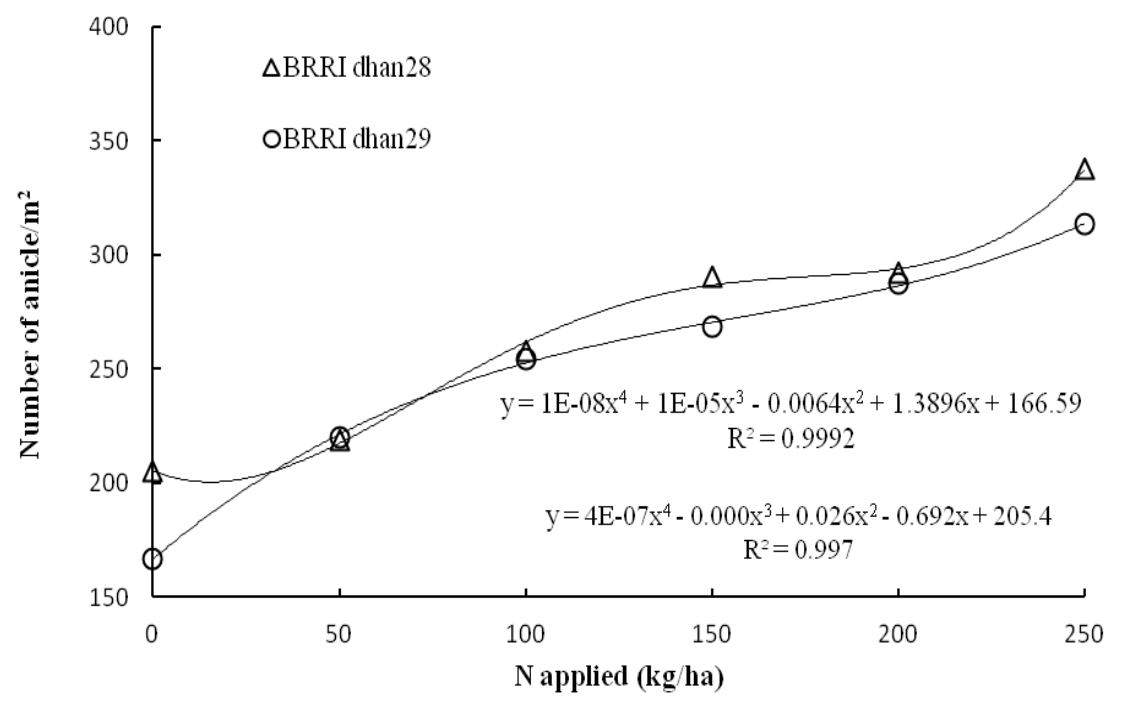

Figure 1. Relationship between $\mathrm{N}$ application and panicle production in two rice varieties

Thousand grain weight ranged from 19 to $20 \mathrm{~g}$ both in BRRI dhan28 and BRRI dhan29 irrespective of $\mathrm{N}$ rates (Table 1). In BRRI dhan28, the sterility percentage ranged from 22 $30 \%$ and in BRRI dhan29, 17-25\% among different $\mathrm{N}$ rates. Panicles per unit area, filled spikelet percentage and 1000 grain weight were major contributors to increase grain yield in modern high yielding rice varieties (Yoshida, 1981).

It was found a quadratic pattern of grain sterility and 1000-grain weight of rice with a range of nitrogen application from 0 to $400 \mathrm{mg} \mathrm{kg}^{-1}$ under pot culture (Fageria et al., 2011). Filled grain per panicle and sterility percentage accounted for 71.1 and $38.0 \%$ variation, respectively, while 1000-grain weight accounted for only $1.1 \%$ variation in the rice yield (Zeng and Shannon, 2000). There is a very close relationship between the yield and its components, especially with number of filled grains per panicle. It was found that application of nitrogen improves various crop parameters like 1000-grain weight, more productive tillers and grain yield thus resulting in higher yields (Chaturvedi, 2005).

\subsection{Grain yield}

Nitrogen (N) and variety (V) demonstrated significant interaction effect on the grain yield $(\mathrm{P}<0.05)$. Grain yield increased with $\mathrm{N}$ fertilization and showed significant $(\mathrm{P}<0.01)$ quadratic response both in BRRI dhan 28 and BRRI dhan29 rice (Figure 2). The quadratic regression equation $(Y=778.5+2069 x-$ $241.7 x^{2}, R^{2}=0.98$ for BRRI dhan 28 and $Y=$ $506.2+2688 x-313.7 x^{2}, R^{2}=0.99$ for BRRI dhan29) explained $98 \%$ of yield variation in BRRI dhan 28 and $99 \%$ in BRRI dhan29 due to applied nitrogen.

Varietal effect was highly significant $(\mathrm{P}<0.01)$ and BRRIdhan29 gage significantly higher yield compared to BRRI dhan28 (Figure 2). Differentiating the quadratic equation of yield response with respect to applied $\mathrm{N}$ doses, the maximum $\mathrm{N}$ rate appeared as $164 \mathrm{~kg} \mathrm{ha}^{-1}$ both for BRRI dhan28 and BRRI dhan29. However, the economic optimum dose appeared as 156 and $158 \mathrm{~kg} \mathrm{ha}^{-1}$ for BRRI dhan28 and BRRI dhan29, respectively (Table 2 ). 


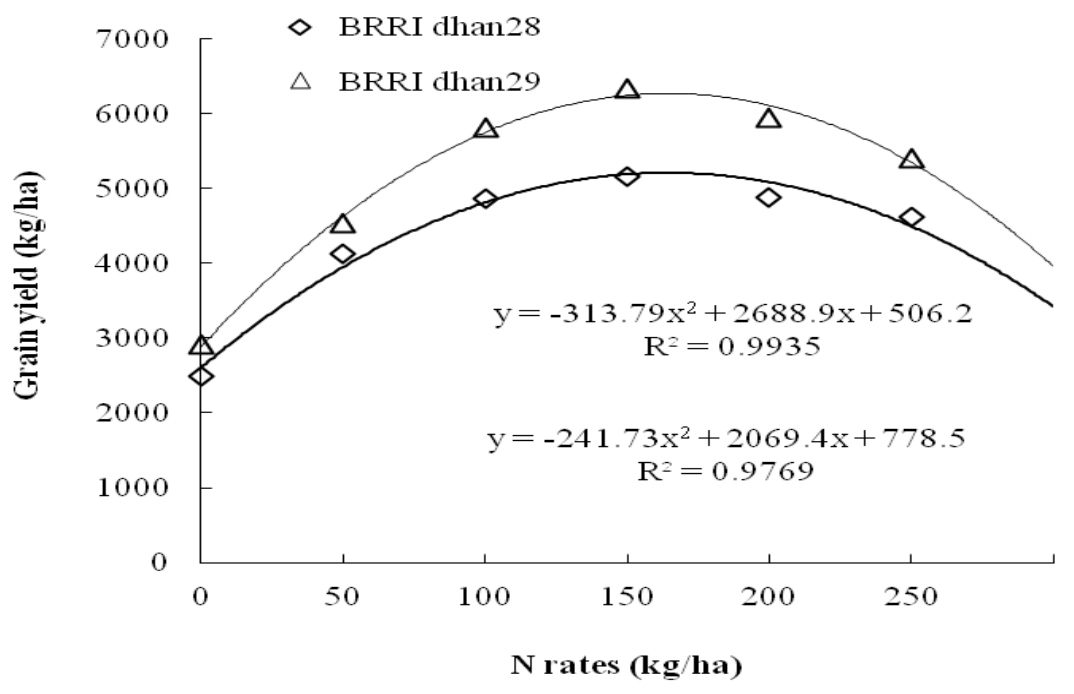

Figure 2. Grain yield of two rice varieties at different rates of $\mathrm{N}$ application

Table 2. Optimum doses of nitrogen for BRRI dhan 28 and BRRI dhan29 in Chhiata clay loam

\begin{tabular}{lcc}
\hline Variety & Optimum dose $\left(\mathrm{kg} \mathrm{ha}^{-1}\right)$ & Economic optimum dose $\left(\mathrm{kg} \mathrm{ha}^{-1}\right)$ \\
\hline BRRI dhan28 & 164 & 156 \\
BRRI dhan29 & 164 & 158 \\
\hline
\end{tabular}

Maximum grain yield of 20 lowland rice genotypes was obtained at $150-200 \mathrm{~kg} \mathrm{~N} \mathrm{ha}^{-1}$ at IRRI in Philippines (Singh et al., 1998). Our results fall more or less in the same range. The $\mathrm{N}$ fertilization significantly increased grain yield and shoot dry weight. The variation in grain yield with nitrogen fertilization varied from 66 to 93\% depending on genotypes (Fageria et al., 2003). It was pointed out that when growth duration is shorter than the optimum, the low yield is caused by shortage of vegetative growth, less number of panicles and less number of spikelets (Vergara et al., 1964). Low yield is explained by relatively lower sink size particularly in varieties with low potential sink size. This is due to low amount of $\mathrm{N}$ in plants at late stage of spikelet initiation. In fertilizer experiments $90 \%$ of the maximum yield is often considered as an economical rate (Fageria et al.,
2003). The $90 \%$ of the maximum grain yield was obtained with the application of $136 \mathrm{~kg} \mathrm{~N}^{-1}$ and $90 \%$ of the maximum shoot dry matter yield was achieved with the application of $120 \mathrm{~kg} \mathrm{~N}$ ha $^{-1}$ (Fageria et al., 2008). Another study revealed that maximum average grain yield of 20 lowland rice genotypes was obtained at 150 to $200 \mathrm{~kg} \mathrm{~N} \mathrm{ha}^{-1}$ (Singh et al., 1998). Similarly, Maximum average grain yield in the dry season at IRRI, Philippines with 120 to $150 \mathrm{~kg} \mathrm{~N}^{-1}$ (Dobermann et al., 2000). Variation of optimum $\mathrm{N}$ doses for rice depends on many abiotic and biotic factors, therefore, it has limited use in a particular geographical and ecological conditions (Tari, 2012). It was observed $120 \mathrm{~kg} \mathrm{~N} \mathrm{ha}^{-1}$ as an optimum dose for a yield level of 7.45 and $6.80 \mathrm{t}$ $\mathrm{ha}^{-1}$ in two consecutive years for direct wet season rice in Indo-Gangetic plain of Ludhiana, India (Singh et al., 2007). 
Nitrogen management significantly influenced grain yield and yield components during wet and dry season. Different N levels had similar yields and yield parameters, which were significantly higher from no $\mathrm{N}$ fertilization in both the seasons (Ali et al., 2012). Rice genotypes were distinguished as efficient, inefficient, and inferior types based on grain yield response in relation to $\mathrm{N}$ response (Gourley et al., 1993). Excessive $\mathrm{N}$ application to rice crop in China causes environmental pollution, increases the cost of rice farming, reduces grain yield and contributes to global warming (Peng et al., 2010). Over-application of $\mathrm{N}$ fertilizer may actually decrease grain yield by increasing susceptibility to lodging (Pham et al., 2004). Grain yield of T. Aman rice increased gradually with the increasing levels of nitrogen upto 150 $\mathrm{kg} \mathrm{N} \mathrm{ha}^{-1}$, but at higher rates $\left(200 \mathrm{~kg} \mathrm{ha}^{-1}\right)$, grain yield tended to decrease in BRRI dhan31 (Salahuddin et al., 2009). Response function, established from the yield and $\mathrm{N}$ data was quadratic in nature. The common equation for all $\mathrm{N}$ obtained was $\mathrm{Y}=3.174+0.022 \mathrm{x}-0.0007 \mathrm{x}^{2}$. The co-efficient of determination $\left(\mathrm{R}^{2}\right)$ indicated that
$85 \%$ of the total variation in the yield can be attributed to the variation in $\mathrm{N}$ alone (Salahuddin et al., 2009).

\subsection{Straw yield}

The interaction effect of $\mathrm{N} x$ variety on straw yield was significant $(\mathrm{P}<0.05)$. Mean effect of $\mathrm{N}$ was also significant $(\mathrm{P}<0.01)$ on the straw yield. The straw yield increased with the increase of $\mathrm{N}$ fertilization and showed quadratic response both in BRRI dhan 28 and BRRI dhan29 rice (Figure $3)$. The quadratic equation $(Y=965.5+1929 x-$ $147.5 x^{2}, R^{2}=0.995$ for BRRI dhan28 and $Y=$ $842.3+3141 x-263.5 x^{2}, \quad R^{2}=0.993$ for BRRI dhan29) could explain $100 \%$ of the relationship for BRRI dhan 28 and $99 \%$ of the relationship in BRRI dhan29. The highest straw yield was obtained with the rate of $250 \mathrm{~kg} \mathrm{~N} \mathrm{ha}^{-1}$ in both the varieties. Varietal effect showed highly significant $(\mathrm{P}<0.01)$ and $\mathrm{BRRI}$ dhan 29 achieved significantly greater straw yield compared to BRRI dhan28 (Figure 3). It was reported highly significant positive correlation between shoot dry weight and grain yield of eight lowland rice genotypes (Fageria and Filho, 2001).

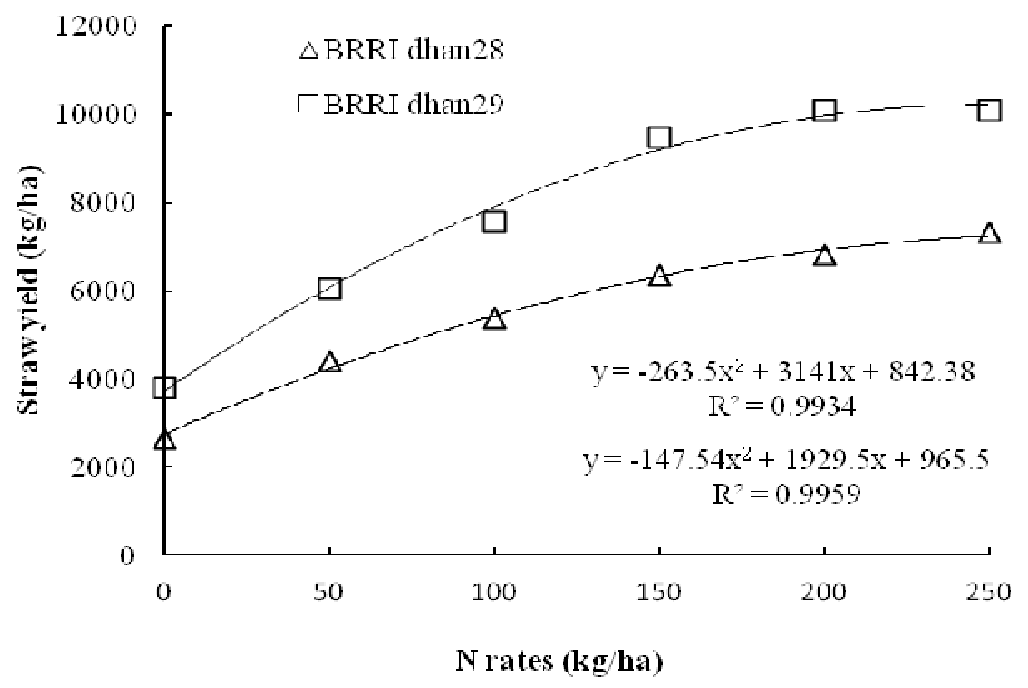

Figure 3. Straw yield of two rice varieties at different rates of $\mathrm{N}$ application 


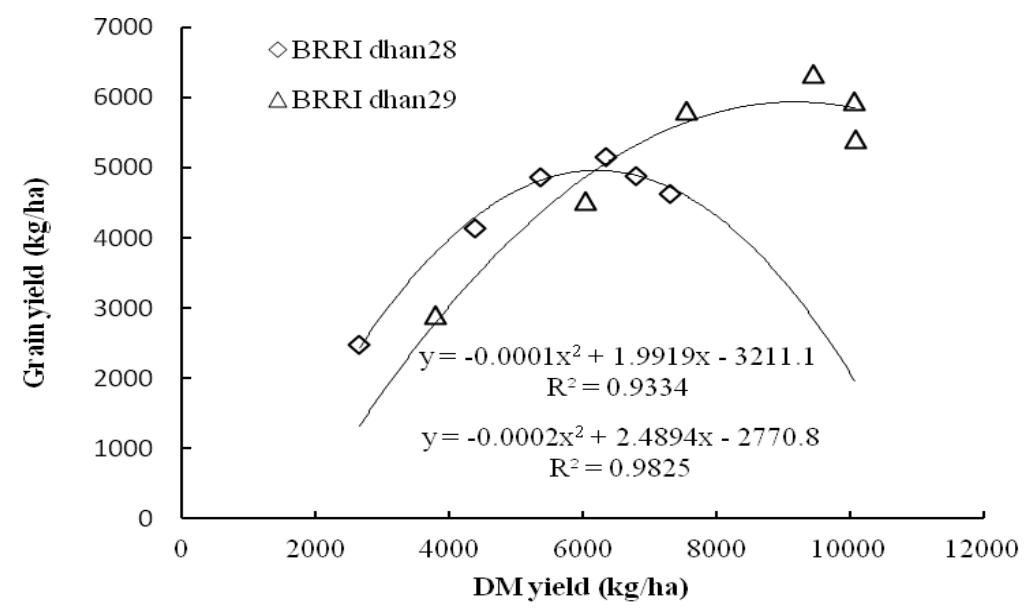

Figure 4. Relationship between DM yield at harvest and grain yield of two rice varieties

Similarly, it was reported that shoot dry weight is an important plant component for determining grain yield in field crops (Fageria and Baligar, 2005). Yield improvement of lowland rice cultivars was come out due to increases of biomass production. This means that genotypes producing the highest grain yield should produce reasonably good dry matter yield (Peng et al., 2000). Variation in shoot dry weight and grain yield may be associated with differences in the amount of intercepted photosynthetically active radiation by the canopy, the radiation use efficiency, and harvest index (Kiniry et al., 2001; Fageria and Baligar, 2005).

\subsection{Relationship between straw and grain yields}

A relationship between dry matter yield at different growth stages and grain yield was determined both for BRRI dhan 28 and BRRI dhan29 (Figure 4). Grain yield increased significantly $(\mathrm{p}<0.01)$ with increasing dry matter production in both the varieties and the relationship was quadratic. The quadratic regression equation $(Y=-2770+2.489 x-$ $0.000 x^{2}, R^{2}=0.982$ for BRRI dhan28 and $Y=-$ $3211+1.991 x-0.000 x^{2}, R^{2}=0.933$ for BRRI dhan29) explained $98 \%$ of the relationship for BRRI dhan 28 and $93 \%$ of the relationship for
BRRI dhan29 (Figure 4). Maximal grain yield of about $5154 \mathrm{~kg} \mathrm{ha}^{-1}$ was achieved at about 6350 $\mathrm{kg} \mathrm{ha}^{-1}$ of dry matter production in BRRI dhan 28 , with a harvest index of about 0.45 . However, grain yield of $6341 \mathrm{~kg} \mathrm{ha}^{-1}$ was achieved at about $9458 \mathrm{~kg} \mathrm{ha}^{-1}$ of dry matter production in BRRI dhan29, with a harvest index of about 0.40 (Figure 4). Grain yield in cereals is related to biological yield and harvest index.

\subsection{Growth parameters and yield components association with grain yield}

In BRRI dhan28, shoot dry weight and number of grains per panicle were significantly related to grain yield (Table 3). Grain yield increased quadratically $\left(Y=-3 E-07 X^{2}-0.002 X-1.695, \mathrm{R}^{2}\right.$ $=0.84$ ) with increasing shoot dry weight. The equation explained that the variability in grain yield was $84 \%$ due to shoot dry weight. The simple linear regression equation was observed in between the number of grains per panicle and grain yield and the equation ( $\mathrm{Y}=0.018 \mathrm{X}+$ $0.043, \mathrm{R}^{2}=0.98$ ) explained that the variability in grain yield was $98 \%$ due to grains number per panicle. In BRRI dhan29, grain yield also increased quadratically $\left(Y=-1 E-07 X^{2}+0.001 X\right.$ $\left.2.107, \mathrm{R}^{2}=0.79\right)$ with increasing shoot dry weight (Table 4) and the variability in grain yield was $79 \%$ due to shoot dry weight. 
Table 3. Relationship between plant growth and yield components $(\mathrm{X})$ and grain yield $(\mathrm{Y})$ of BRRI dhan 28 rice variety

\begin{tabular}{lcccc}
\hline Variable & \multicolumn{1}{c}{ Regression equation } & $\mathrm{R}^{2}$ & F-value & $\begin{array}{c}\text { Probability } \\
\text { levels }\end{array}$ \\
\hline $\begin{array}{l}\text { Plant height vs. grain } \\
\text { yield }\end{array}$ & $\mathrm{Y}=-1.827+0.065 \mathrm{X}$ & $0.628^{\mathrm{NS}}$ & 6.75 & 0.06 \\
$\begin{array}{l}\text { Shoot dry weight vs. } \\
\text { grain yield }\end{array}$ & $\mathrm{Y}=-3 \mathrm{E}-07 \mathrm{X}^{2}-0.002 \mathrm{X}-1.695$ & $0.836^{*}$ & 7.65 & 0.07 \\
$\begin{array}{l}\text { Panicle number vs. grain } \\
\text { yield }\end{array}$ & $\mathrm{Y}=-5 \mathrm{E}-05 \mathrm{X}^{2}+0.035 \mathrm{X}-1.996$ & $0.400^{\mathrm{NS}}$ & 1.00 & 0.46 \\
$\begin{array}{l}\text { Grain harvest index vs. } \\
\text { grain yield }\end{array}$ & $\mathrm{Y}=-2.053 \mathrm{X}+4.476$ & $0.180^{\mathrm{NS}}$ & 0.88 & 0.40 \\
$\begin{array}{l}1000 \text { grain weight vs. } \\
\text { grain yield }\end{array}$ & $\mathrm{Y}=-0.366 \mathrm{X}+10.80$ & $0.045^{\mathrm{NS}}$ & 0.19 & 0.69 \\
$\begin{array}{l}\text { Grain sterility vs. grain } \\
\text { yield }\end{array}$ & $\mathrm{Y}=-0.089 \mathrm{X}+5.730$ & $0.233^{\mathrm{NS}}$ & 1.22 & 0.33 \\
$\begin{array}{l}\text { Grains number vs. grain } \\
\text { yield }\end{array}$ & $\mathrm{Y}=0.018 \mathrm{X}+0.043$ & $0.977^{* *}$ & 169.91 & 0.00 \\
\hline
\end{tabular}

*,**, ${ }^{\mathrm{NS}}$ significant at the 0.05 and 0.01 probability levels and non-significant, respectively.

Table 4. Relationship between plant growth and yield components (X) and grain yield (Y) of BRRI dhan29 rice variety

\begin{tabular}{lllll}
\hline \multicolumn{1}{c}{ Variable } & \multicolumn{1}{c}{ Regression equation } & $\mathrm{R}^{2}$ & F-value & $\begin{array}{c}\text { Probability } \\
\text { levels }\end{array}$ \\
\hline $\begin{array}{l}\text { Plant height vs. } \\
\text { grain yield }\end{array}$ & $\mathrm{Y}=-3.247+0.093 \mathrm{X}$ & $0.348^{\mathrm{NS}}$ & 2.13 & 0.22 \\
$\begin{array}{l}\text { Shoot dry weight } \\
\text { vs. grain yield }\end{array}$ & $\mathrm{Y}=-1 \mathrm{E}-07 \mathrm{X}^{2}+0.001 \mathrm{X}-2.107$ & $0.785^{\mathrm{NS}}$ & 5.48 & 0.10 \\
$\begin{array}{l}\text { Panicle number vs. } \\
\text { grain yield }\end{array}$ & $\mathrm{Y}=-0.000 \mathrm{X}^{2}+0.105 \mathrm{X}-9.164$ & $0.778^{\mathrm{NS}}$ & 5.26 & 0.10 \\
$\begin{array}{l}\text { Grain harvest } \\
\text { index vs. grain } \\
\text { yield }\end{array}$ & $\mathrm{Y}=-146.2 \mathrm{X}^{2}+103.0 \mathrm{X}-13.28$ & $0.297^{\mathrm{NS}}$ & 1.69 & 0.26 \\
$\begin{array}{l}1000 \text { grain weight } \\
\text { vs. grain yield }\end{array}$ & $\mathrm{Y}=-0.343 \mathrm{X}+11.02$ & $0.038^{\mathrm{NS}}$ & 0.16 & 0.71 \\
$\begin{array}{l}\text { Grain sterility vs. } \\
\text { grain yield }\end{array}$ & $\mathrm{Y}=-0.070 \mathrm{X}+5.979$ & $0.096^{\mathrm{NS}}$ & 0.42 & 0.55 \\
$\begin{array}{l}\text { Grains number vs. } \\
\text { grain yield }\end{array}$ & $\mathrm{Y}=0.018 \mathrm{X}+0.001$ & $0.995^{* *}$ & 796.00 & 0.00 \\
\hline
\end{tabular}

*,**, ${ }^{\mathrm{NS}}$ significant at the 0.05 and 0.01 probability levels and non-significant, respectively.

Similarly, grain yield increased significantly $(\mathrm{P}<0.01)$ and linearly with increasing number of grains per panicle and the simple regression equation explained that the variability in grain yield was $99 \%$ due to grains number per panicle (Table 4). Plant height, panicle number and 
grains sterility were not significantly related to grain yield. In BRRI dhan28, the variability in grain yield was $63 \%$ due to plant height, $40 \%$ due to panicle number per unit area, $18 \%$ grain harvest index and $23 \%$ due to grains sterility (Table 3). In BRRI dhan29, the variability in grain yield was $35 \%$ due to plant height, $78 \%$ due to panicle number per unit area and 30\% grain harvest index (Table 4). Plant height, shoot dry weight, panicle number, harvest index and root dry weight was significantly related to grain yield (Fageria et al., 2011). It was also reported that rice yield was highly correlated with shoot dry weight, panicle number and harvest index. This means that it is possible to manipulate these yield parameters with $\mathrm{N}$ treatments in favour of higher grain yield in rice (Fageria et al., 1997; Fageria, 2007).

\section{Conclusions}

Grain yield, yield components and straw yield of rice grown in Chhita clay loam soil were significantly influenced by $\mathrm{N}$ rates. BRRI dhan29 produced about $1.0 \mathrm{t} \mathrm{ha}^{-1}$ more grain than the BRRI dhan 28 and $\mathrm{N}$ requirement for both the varieties appeared to be the same. Application of $\mathrm{N}$ fertilizer increased grain yield by about 3-4 $\mathrm{t}$ $\mathrm{ha}^{-1}$ compared to control in BRRI dhan 28 and BRRI dhan29. The economic optimum rate of $\mathrm{N}$ for BRRI dhan 28 and BRRI dhan29 appeared as about $160 \mathrm{~kg} \mathrm{~N} \mathrm{ha}^{-1}$.

\section{References}

Ali, M. K., Ladha, J. K., Rickman, J., Lales, J. S. and Alam, M. M. 2012. Evaluation of drill seeding patterns and nitrogen management strategies for wet and dry land rice. Bangladesh Journal of Agricultural Research, 37:559-571.

Buresh, R. J., Garrity, D. P., Castillo, E. G., Chua T. T., Fallow and Sesbanis. 1993. Effects on response of transplanted lowland rice to Urea. Agronomy Journal, 85: 801-808.
Cassman, K. G., Dobermann, A. and Walters, D. T. 2002. Agroecosystems, nitrogen-use efficiency, and nitrogen management. Royal Swedish Academy of Sciences. Ambio, 31 March 2002.

Chaturvedi, I. 2005. Effect of nitrogen fertilizers on growth, yield and quality of hybrid rice. Journal of Central European Agriculture, 6: 611-618.

Colwell, J. D. 1994. Estimating fertilizer requirements: A quantitative approach. CAB International, Wallingford, Oxon OX 10SDE, UK.

Dawe, D., Dobermann, A., Moya, P., Abulrachmann, S., Singh, B., Lal, P., Li, S. Y., Lin, B., Panaullah, G. M., Sariam, O., Singh, Y., Swarup, A., Tan, P. S. and Zhen, Q. X. 2000. How widespread are yield declines in long-term rice experiments in Asia? Field Crops Research, 66: 175-193.

Dobermann, A., Dawe, D., Roetter, R. P. and Cassman, K. G. 2000. Reversal of rice yields decline in a long term continuous cropping experiment. Agronomy Journal, 92: 633-643.

Fageria, N. K., Moreira, A. and Coelho, A. M. 2011. Yield and yield components of upland rice as influenced by nitrogen sources. Journal of Plant Nutrition, 34: $361-370$.

Fageria, N. K. 2007. Yield physiology of rice. Journal of Plant Nutrition, 30: 843-879.

Fageria, N. K. and Filho, M. P. B. 2001. Nitrogen use efficiency in lowland rice genotypes. Communications in Soil Science and Plant Analysis, 32: 20792089.

Fageria, N. K. and Baligar, V. C. 1999. Yield and yield components of lowland rice as influenced by timing of nitrogen fertilization. Journal of Plant Nutrition, 22: 23-32. 
Fageria, N. K. and Baligar, V. C. 2001. Lowland rice response to nitrogen fertilization. Communications in Soil Science and Plant Analysis, 32: 1405-1429.

Fageria, N. K. and Baligar, V. C. 2005. Enhancing nitrogen use efficiency in crop plants. Advances in Agronomy, 88: 97185.

Fageria, N. K., Santos, A. B and Cutrim, V. A. 2008. Dry matter and yield of lowland rice genotypes as influence by nitrogen fertilization. Journal of Plant Nutrition, 31: 788-795.

Fageria, N. K., Santos, A. B. and Baligar, V. C. 1997. Phosphorus soil test calibration for lowland rice on an Inceptisol. Agronomy Journal, 89: 737-742.

Fageria, N. K., Stalon, N. A. and Baligar, V. C. 2003. Nutrient management for improving lowland rice productivity and sustainability. Advances in Agronomy, 80: 63-152.

Gomez, K. A. and Gomez, V. C. 1984. Statistical procedure for agricultural research $\left(2^{\text {nd }}\right.$ ed.). John Willey and Sons, Singapore, 28-192 pp.

Gourley, C. J. P., Allan, D. L. and Russelle, M. P. 1993. Defining phosphorus efficiency in plant. In: Plant nutrition from genetic engineering to field practice, (ed.) N.J. Barrow, Kluwer Academic Publishers, 363-366 pp.

Khatun, A., Sultana, H., Bhuiya, M. S. U. and Saleque, M. A. 2015a. Nitrogen use efficiency of low land rice as affected by organic and chemical sources. Open Access Library Journal, 2: http://dx.doi.org/10.4236/oalib.1101327

Khatun, A., Quais, M. K., Sultana, H., Bhuiyan, M. K. A. and Saleque, M. A. 2015b. Nitrogen fertilizer optimization and its response to the growth and yield of lowland rice. Research on Crop Ecophysiology, 10:1-16.
Kiniry, J. R., McCauley, G., Xie, Y. and Arnold, J. G. 2001. Rice parameters describing crop performance of four U. S. cultivars. Agronomy Journal, 93: 1354 -1361.

Peng, S., Laza, R. C., Visperas, R. S., Sanico, A. L., Cassman, K. G. and Khush, G. S. 2000. Grain yield of rice cultivars and lines in the Philippines since 1966. Crop Science, 40: 307-314.

Peng, S., Buresh, R. J. Huang, J., Zhong, X., Zou, Y., Yang, J., Wang, G., Liu, Y., Hu, R., Tang, Q., Cui, K., Zhang, F. and Dobermann, A. 2010. Improving nitrogen fertilization in rice by site-specific $\mathrm{N}$ management: A review. Agronomy for Sustainable Development, 30: 649-656.

Pham, Q. D., Abe, A., Hirano, M., Sagawa, S. and Kuroda, E. 2004. Analysis of lodgingresistant characteristics of different rice genotypes grown under the standard and nitrogen-free basal dressing accompanied with sparse planting density practices. Plant Production Science, 7: 243-251.

Salahuddin, K. M., Chowhdury, S. H., Muniram. S., Islam, M. and Parvin, S. 2009. Response of nitrogen and plant spacing of transplanted aman rice. Bangladesh Journal of Agricultural Research, 34: 279-285.

Saleque, M. A., Abedin, M. J., Bhuiyan, N. I., Zaman, S. K. and Panaullah, G. M. 2004. Long-term effects of inorganic and organic fertilizer sources on yield and nutrient accumulation of lowland rice. Field Crops Research, 86: 53-65.

Singh, U., Ladha, J. K., Castillo, E. G., Punjalan, G., Tirol-Padre, A. and Duqueza, M. 1998. Genotypic variation in nitrogen use efficiency in medium and long duration rice. Field Crop Research, 58: 35-53.

Singh, Y., Gupta, R. K., Singh, B. and Gupta, S. 2007. Efficient management of fertilizer nitrogen in wet direct-seeded rice (Oryza 
sativa) in northwest India. Indian Journal of Agricultural Science, 77: 561- 564.

Tari, D. B. 2012. Determination of nitrogen fertilization effect at different transplanting dates on rice yield and yield traits. American-Eurosean Journal of Agricultural and Environmental Science, 12: $678-681$.

Vergara, B. S., Lilis, R. and Tanaka, A. 1964. Relationship between length of growing period and yield of rice plants under a limited nitrogen supply. Soil Science and Plant Nutrition, 10: 59-65.
Yoshida, S. 1981. Fundamentals of rice crop science. IRRI, Los Banos, Philippines, 235-237 pp.

Yoshida, S., Forno, D. A., Cock, J. H. and Gomez, K. A. 1976. Laboratory Manual for Physiological Studies of Rice. $3^{\text {rd }}$ ed. International Rice Research Institute, Manila, Philippines, 74-78 pp.

Zeng, L. and Shannon, M. S. 2000. Salinity effects on seedling growth and yield components of rice. Crop Science, 40: 996-1003. 